\title{
ARTICLE
}

\section{The humid and thermal impact on distribution of Sea buckthorn fly (Rhagolethis batava Hering, 1958) in Mongolia}

\author{
Munkhtsetseg Baasan ${ }^{1 *}$, Turbat Tumurbaatar ${ }^{2}$ and Dorjderem Balchin ${ }^{3}$ \\ ${ }^{1}$ Laboratory of Entomology, Institute of Plant Protection, \\ Ulaanbaatar, Mongolia \\ ${ }^{2}$ Agrometeorological Research Division, Information and Research \\ Institute of Meteorology, Hydrology and Environment, Ulaanbaatar, Mongolia \\ ${ }^{3}$ Laboratory of Plant Introduction and Genetic resources, Botanic garden and Research Institute, \\ Mongolian Academy of Sciences, Ulaanbaatar, Mongolia
}

ARTICLE INFO: Received: 13 Feb, 2021; Accepted: 31 Aug, 2021

Abstract: A total of 80 species in 1834 types of Tephritidae Newman (fruit flies) were recorded in the Mongolian-Russian comprehensive and joint expedition report, which was organized in 1967-1995. In the course of an itinerary survey conducted in 2019, we have recorded the dispersion of Rhagoletis batava at 223 natural (wild) and planted sea buckthorn points in 22 soums of Bayan-Ulgii, Uvs, Zavkhan, Khovd, Selenge and Govi-Altai aimags (provinces).

Accordingly, we summarized the spread of sea buckthorn fruit fly relating mostly to territories that have dry and cooler climates, while some areas are humid and cold. Based on the dispersion points, we determined the current and future changes in the distribution of this species of flies, using the MaxEnt Modeling of geographical distribution. Thermal and humidity rates that affect the flies were estimated using data collected from 18 meteorological stations and sentinel posts. These points are located in different natural zones with an average annual air temperature fluctuating from -4.8 to $3.2^{\circ} \mathrm{C}$. For example, in Tes soum of Uvs aimag, Bayantes soum of Zavkhan aimag and in Tes along the Tes river basin the average annual temperature is from -3.7 to $-4.8^{\circ} \mathrm{C}$; in Baitag Kharuul of Bulgan soum of Khovd aimag, along the Bulgan river basin, the warmest temperature is $3.2^{\circ} \mathrm{C}$, and in other soums it is $-2.4 \ldots 1.8^{\circ} \mathrm{C}$.

Keywords: Sea buckthorn fly; Rhagolethis batava; dispersion; distribution;

\section{INTRODUCTION}

The tribe of Rhagoletis batava is a species of fruit fly, whose larvae feed on the flesh of Hippophae rhamnoides (Elaeagnaceae) - sea buckthorn fruit. In terms of classification, it belongs to the order of Diptera, family of fruit fly (Tephritidae) and genus Rhagoletis. As of today, 4350 species in 480 types of Tephritidae Newman and around 850 species of Palearctic have been recorded in all geographical regions and territories.

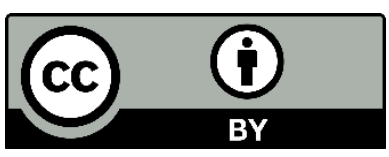

The Author(s). 2021 Open access This article is distributed under the terms of the Creative Commons Attribution 4.0 International License (https://creativecommons.org/licenses/by/4.0/), which permits unrestricted use, distribution, and reproduction in any medium, provided you give appropriate credit to the original author(s) and the source, provide a link to the Creative Commons license, and indicate if changes were made. 
But, 36 types and 98 species from 11 tribes were revealed in the Southeast of Western Siberia.

To date, 62 species in 1863 types of Rhagoletis Loew were recorded. Hering was the first to determine the Rhagoletis batava in 1958 and later by Rohdendorf in 1961; Kandybina determined it in 1977; White \& Elson-Harris in 1992; Merz in 2001; Norrbom et al., in 1999 and Smit determined it in 2010.

It is a Palearctic species and is widespread in Central and Western Europe, Central Asia, the Caucasus, Russia, Altai Region, the desert in the Great Lakes Depression, forest steppe, large river valleys of our country; around Uvs Lake, Kharkhiraa, Turgen River, Khovd River, Bulgan River and Zavkhan River basins. The female fly lay their eggs by pricking the surface of the fruit skin, and as soon as the larvae are born, they enter inside the fruit and feed on the soft tissue of the fruit flesh. The number of fruits damaged by one larva varies depending on the size of the fruit. Usually 1-2 fruits are damaged, the color of the damaged fruit begins to change and turns yellowish, shrinks, darkens, warps and then dries.

Sainzaya's (2014) observation of sea buckthorn field in the center of Uvs aimag was similar to that of Chuluunjav's (2014)

\section{MATERIALS AND METHODS}

We processed the 20-year's average tenday data series of meteorological stations and security point's precipitation, air and soil temperature, and average wind speed for 19992019 and calculated the multi-year mean (MYM) values in Bayannuur, Bulgan, Nogoonnuur, Tsengel, Ulaankhus and Sagsai soums of Bayan-Ulgii aimag, Tes, Khovd and Ulaangom soums of Uvs aimag, Aldarkhaan, Durvuljin and Tes soums of Zavkhan aimage, Bulgan and Erdeneburen soums of Khovd aimag, Zuunburen station of Selenge aimag and Choir soum of Govisumber aimag. Using the future climate change scenario (Gomboluudev, 2018), which estimated greenhouse gas (GHG) emissions at RCP8.5 using the HadGEM atmospheric general circulation model, we calculated the results of twenty-year average observation, but differs in the early stages of mating and spawning. According to Sainzaya's research, the flight began when the temperature was higher than plus $18^{\circ} \mathrm{C}$, and increased sharply when it was above $22-23^{\circ} \mathrm{C}$. It has been also noted that the soil temperature at the time of emergence from the soil has a strong effect on flies. According to Zeynalov (many years in Russia), the fly's flight takes place at a temperature of $252.1-319^{\circ} \mathrm{C}$, ovulation 339.5 $390.30^{\circ} \mathrm{C}$, larval development $428.3-470.00^{\circ} \mathrm{C}$ and lasts 48-57 days per offspring. (Zeynalov AS 2018).

In this study, we aimed to determine the distribution of sea buckthorn flies on the territory of Mongolia, map them, and determine the time of their development and disappearance.For this purpose, data from the Meteorological stations, in the soums where the flies were prevalent, related to rainfall in Baitag Kharuul of Bulgan soum in Khovd aimag for 1999-2019, air and soil temperature, and average wind speed for 20 years were processed in a series of ten-day average data, including multi-year value (MYV), and the results of 20year average temperature and precipitation changes in 2050 (2046-2065) and 2080 (20812100) were all used to calculate the distribution of sea bucktorn flies.

temperature and precipitation changes in 2050 (2046-2065) and 2080 (2081-2100), and made 1999-2019 as the base year (precipitation, temperature).

The time for flies to emerge (appear) and disappear is calculated as the period of warming and cooling of the air at a constant temperature of $10^{\circ} \mathrm{C}$ and its mapping was developed using "Natural Zones and Belts", 2009 shapefile, geographic information ARCGIS-10.2, and digital processing using Microsoft Excel 2013 software. The "MaxEnt-Geographical spread and distribution" model was used to calculate the change in the spread of flies. The following information was used for model input. These include: biological data or coordinates of Sea buckthorn flies' distribution points (Excel*.CSV file), environmental data or 
climate (precipitation, present and future changes in temperature), forest, soil, and environmental area maps which were prepared in ArcGIS *. asc. Also, we calculated profitability and active temperature at which flies develop. Insect development does not take place at any temperature, but above a certain temperature range $\left(10^{\circ} \mathrm{C}\right)$, and this is called effective temperature, and it is the temperature that is above the lower limit of development.

$$
t_{a}=t-C
$$

$t_{a}$ - effective temperature,

$C$ - temperature limit,

$t$-ambient temperature of insects.

Sum of effective or profitability temperature:

This parameter is a continuous (integral) indicator which presents the rhythm (rate) of insect development at ambient temperature.

$$
K_{1}=n \cdot t_{a} ; \quad K_{1}=n \cdot(t-C)
$$

$K_{l}$ - sum of effective temperature.

$n, C, t-$ similar to previous.

\section{RESULTS AND DISCUSSIONS}

In the research work, our team selected meteorological stations and security points in soums along the major rivers such as Khovd, Buyant, Bulgan in the Uvs Lake basins, Tes and
Under normal living conditions, the sum of effective temperatures (above a certain limit) and the duration of development are constant.

Sum of active temperature:

We calculated the sum of active temperatures by crossing a certain limit $\left(10^{\circ} \mathrm{C}\right)$ of the average air temperature and adding the temperature between the stable transition periods.

Humidity and thermal coefficient (Insect life expectancy) (Druzhelyubova, Makarova, 1972).

Humidity and heat coefficients affecting the flies are considered to be 1.0-1.5 suitable, over 1.6-excess, 1.0-insufficient and 0.5-less humidity.

$$
G T C=\frac{R R \cdot 10}{\sum T u}
$$

GTC - humidity and heat coefficient (HHC):

$R R$ - insect generation (stage) whole

precipitation,

$\sum T u-$ sum of active temperature.
Zavkhan rivers south of the Khangai Mountains, and we marked a total 223 locations, which recorded the spread of flies on the map (Figure 1).

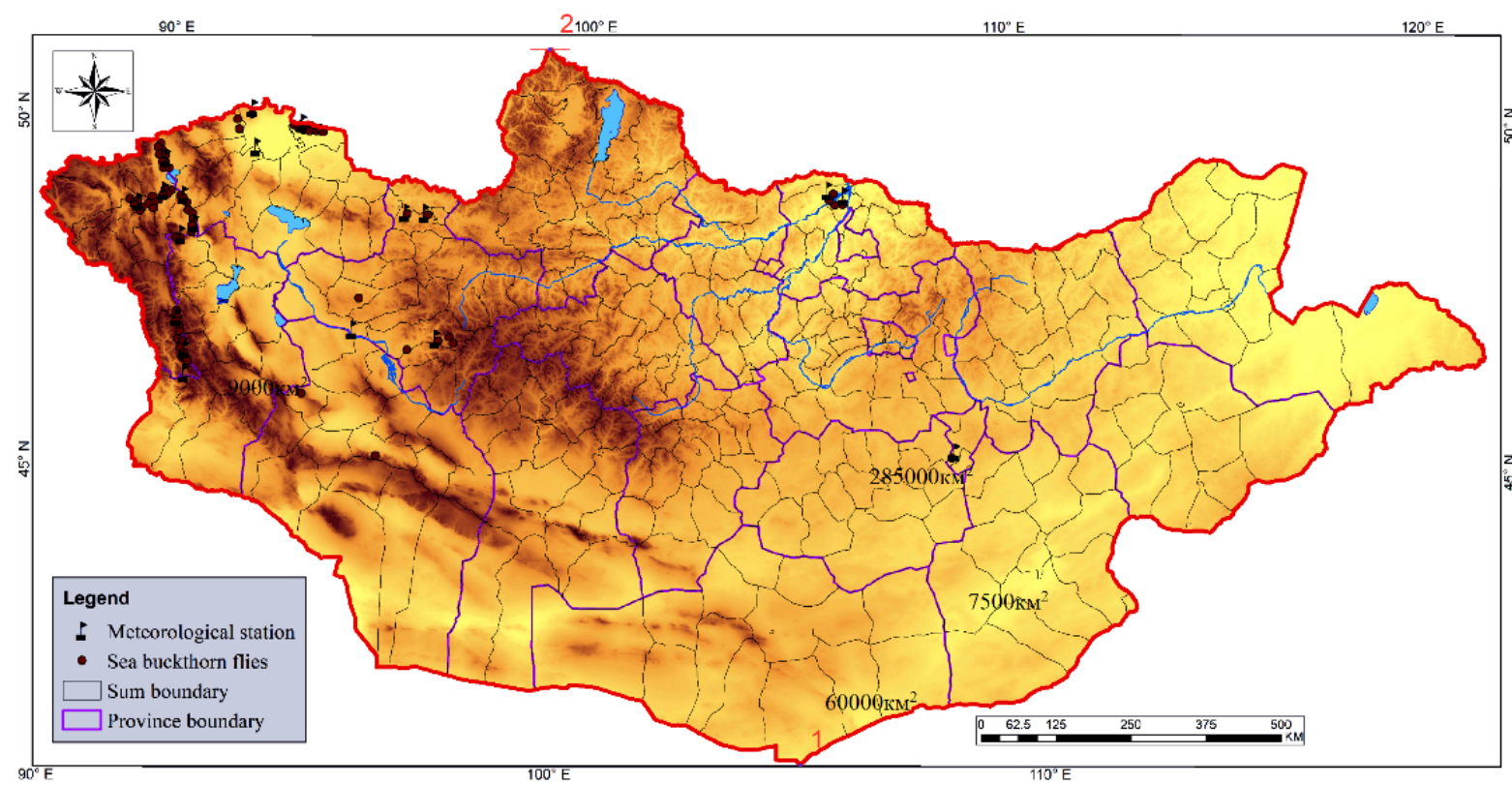

Figure 1. Distribution map of Sea buckthorn flies in Mongolia. 2019 (Marked the distribution of flies along Khovd, Buyant, Bulgan rivers originating from the Altai mountain ranges, Tes river along the Uvs lake basin, and Zavkhan river along the Khangai mountain range. 223 points) 
These points are located in different natural zones and the average annual air temperature is from -4.8 to $3.2^{\circ} \mathrm{C}$ and Tes in Uvs aimag and Bayantes and Tes in Zavkhan aimag along the Tes river basin is from -3.7 to $-4.8^{\circ} \mathrm{C}$, Baitag security point of Bulgan soum of Khovd aimag along the Bulgan river basin is the warmest or measures at $3.2^{\circ} \mathrm{C}$ and in other soums, the average annual air temperature is from -2.4 to $1.8^{\circ} \mathrm{C}$. The average soil temperature has a significant effect on the growth and development of an insect, wintering, emerging in the spring, and disappearing in the fall.

The average soil temperature is from -5.2 to $5.5^{\circ} \mathrm{C}$, which is significantly different from the average air temperature $(-0.4 \ldots 2.3)$. The volume and distribution of precipitation is not very similar, as Sea buckthorn flies covered areas with a unique and comprehensive system of mountains and deserts. As of the total annual precipitation, it is 266.7-273.9 $\mathrm{mm}$ in Tsagaannuur and Zuunburen soums of Selenge aimag, $83.6 \mathrm{~mm}$ in Nogoonnuur soum of
Bayan-Ulgii aimag and only $84.0 \mathrm{~mm}$ in Durvuljin soum of Zavkhan aimag. Also, Tsagaannuur and Zuunburen soums have the highest annual precipitation in August, while Nogoonnuur soum has the highest precipitation in July. During the warm season or active time of insect development, 208.1-237.2 $\mathrm{mm}$ of precipitation fall in Tsagaannuur and Zuunburen soums, and 69.6-72.5 $\mathrm{mm}$ in Nogoonnuur and Durvuljin soums. The average wind speed is $1.1-3.0 \mathrm{~m} / \mathrm{s}$.

\section{Humidity and heat influence the present and future spread of Sea buckthorn fly}

As of multi-year mean (1999-2019), the flies start appearing in Bayan-Ulgii aimag, from April 24 to May 16, in Zavkhan from April 26 to June 5, in Uvs from April 28 to May 3, in Khovd April $16-19$, in Selenge from April 28, May 1, and in Choir April 29, but in 2050, flies are expected to appear earlier by 13-18 days in Bayan-Ulgii, 11-14 days in Uvs and Khovd, 46 days in Zavkhan (46 in Aldarkhaan), 11-16 days in Selenge and 12 days in Choir.

Table 1. Estimation of the time of emergence and disappear of Sea buckthorn fly (Rhagoletis batava) in spring and autumn

\begin{tabular}{|c|c|c|c|c|c|c|c|c|c|c|c|}
\hline \multirow{2}{*}{ № } & \multirow{2}{*}{ Province } & \multirow{2}{*}{ Soum } & \multicolumn{3}{|c|}{ Emergence (appear) } & \multicolumn{3}{|c|}{ Disappear } & \multicolumn{3}{|c|}{ Living period, days } \\
\hline & & & MYM & 2050 & 2080 & MYM & 2050 & 2080 & MYM & 2050 & 2080 \\
\hline 1 & Bayan-Ulgii & Bayan-nuur & 24-Apr & 6-Apr & 1-Apr & 11-Sep & 21-Sep & 29-Sep & 140 & 168 & 181 \\
\hline 2 & Bayan-Ulgii & Duchinjil & 14-May & 29-Apr & 11-Apr & 29-Aug & 13-Sep & 23-Sep & 107 & 137 & 165 \\
\hline 3 & Bayan-Ulgii & Nogoonnuur & 2-May & $15-A p r$ & 4-Apr & $7-\mathrm{Sep}$ & 17-Sep & 26-Sep & 128 & 155 & 175 \\
\hline 4 & Bayan-Ulgii & Sagsai & 9-May & 24-Apr & 11-Apr & 29-Aug & 11-Sep & 21-Sep & 112 & 140 & 163 \\
\hline 5 & Bayan-Ulgii & Ulaankhus & 11-May & 26-Apr & 12-Apr & 29-Aug & 11-Sep & 20-Sep & 110 & 138 & 161 \\
\hline 6 & Bayan-Ulgii & Tsengel & 16-May & 3-May & 20-Apr & 25-Aug & 9-Sep & 18-Sep & 101 & 129 & 151 \\
\hline 7 & Gobi-Sumber & Choir & 29-Apr & 17-Apr & $8-\mathrm{Apr}$ & 13-Sep & 23-Sep & 30-Sep & 137 & 159 & 175 \\
\hline 8 & Zavkhan & Aldarkhaan & 5-Jun & 20-Apr & 6-Apr & 4-Sep & 14-Sep & 24-Sep & 91 & 147 & 171 \\
\hline 9 & Zavkhan & Bayantes & 13-May & 30-Apr & 19-Apr & 27-Aug & 9-Sep & 17-Sep & 106 & 132 & 151 \\
\hline 10 & Zavkhan & Durbuljin & 26-Apr & 9-Apr & 2-Apr & 12-Sep & 22-Sep & 1-Oct & 139 & 166 & 182 \\
\hline 11 & Zavkhan & Tes & 6-May & 25-Apr & 16-Apr & 31-Aug & 11-Sep & 19-Sep & 117 & 139 & 156 \\
\hline 12 & Selenge & Zuunburen & 28-Apr & 13-Apr & 6-Apr & 6-Sep & 16-Sep & 23-Sep & 131 & 156 & 170 \\
\hline 13 & Selenge & Tsagaannuur & 1-May & $15-\mathrm{Apr}$ & 6-Apr & 8-Sep & $20-$ Sep & 28-Sep & 130 & 158 & 175 \\
\hline 14 & Ubs & Davst & 28-Apr & 17-Apr & 7-Apr & 11-Sep & 20-Sep & 28-Sep & 136 & 156 & 174 \\
\hline 15 & Ubs & Tes & 3-May & 21-Apr & 12-Apr & 6-Sep & 16-Sep & 23-Sep & 126 & 148 & 164 \\
\hline 16 & Ubs & Ulaangom & 29-Apr & 17-Apr & 7-Apr & 9-Sep & 19-Sep & 28-Sep & 133 & 155 & 174 \\
\hline 17 & Khovd & Baitag & 16-Apr & 3-Apr & 27-Mar & 18-Sep & 28-Sep & 6-Oct & 155 & 178 & 193 \\
\hline 18 & Khovd & Erdeneburen & 19-Apr & 5-Apr & 30-Mar & 14-Sep & 24-Sep & 2-Oct & 148 & 172 & 186 \\
\hline
\end{tabular}

As of multi-year mean, in 2080 the flies are expected to appear one month earlier in soums of Bayan-Ulgii aimag and 20-24 days in other aimags, while they are expected to appear earlier or by 60 days earlier in Aldarkhaan soum of Zavkhan aimag (Table 1). In Aldarkhaan soum of Zavkhan, the minimum generation period for flies is 91 days, while in Bulgan soum (Baitag station) of Khovd, it is 155 days. 
The generation period is estimated to be extended by 20 to 30 days in these soums by
2050 (Figure 2). By 2080, this period is expected to increase by $25-88$ percent.

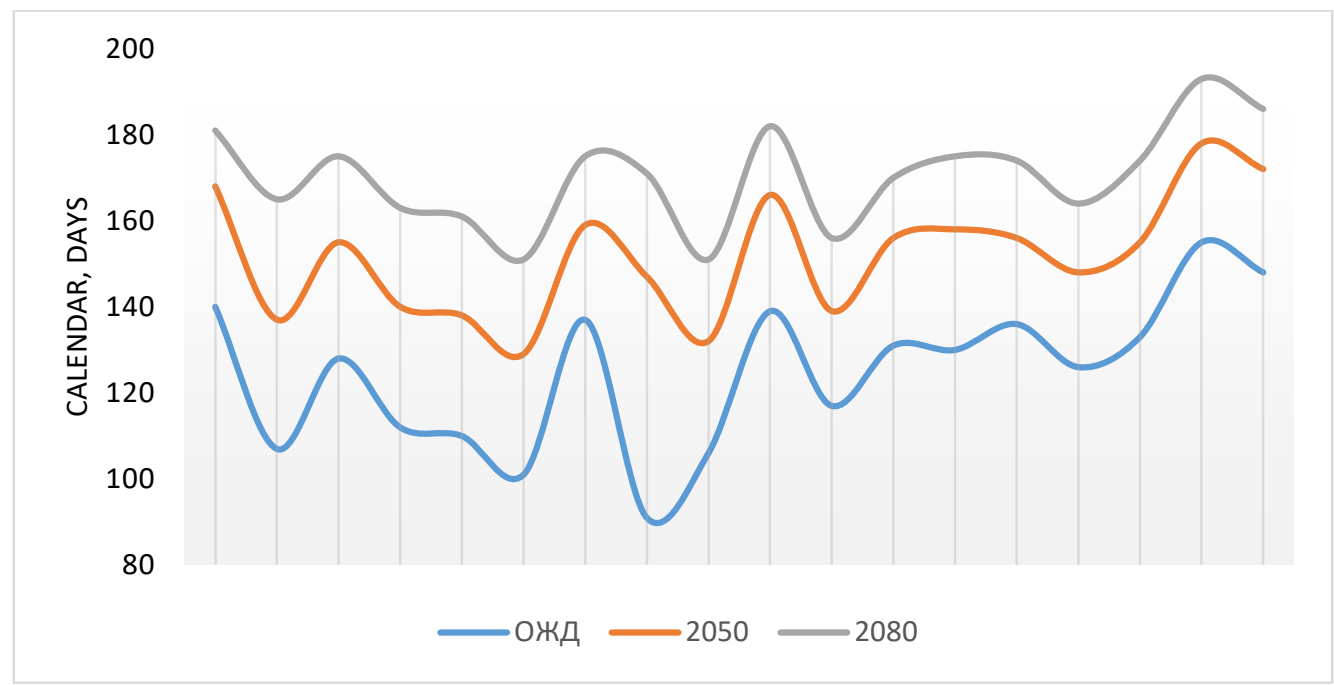

Figure 2. Changes in the lifetime of Seabuckthorn fly, days

Remarks: 1. Bayannuur. 2. Duchinjil. 3.Nogoonnuur. 4.Sagsai. 5.Ulaankhus. 6.Tsengel. 7.Choir. 8. Aldarkhaan. 9. Bayantes. 10. Durvuljin. 11. Tes (Zavkhan). 12. Zuunburen.13. Tsagaannuur. 14. Davst. 15. Tes. 16. Ulaangom. 17. Erdeneburen. ОЖД- multi-year mean

Insect-friendly temperatures are expected to exceed $100^{\circ} \mathrm{C}$ in Choir and Durvuljin soums of Zavkhan, Davst soum of Uvs, Bulgan soum and Erdeneburen of Khovd and to increase by 50 percent in 2050 and 100 percent in 2080. In Bulgan (Duchinjil station) soum of BayanUlgii, the heat supply is low or less than $500^{\circ} \mathrm{C}$. It is also expected to increase by $50-100 \%$ in the future. As the lifetime of flies increases, the heat supply increases as well. According to a multi-year mean, HHC was not enough for flies (suitable for Selenge), it is expected to be less surrounded and less humid in the future.

Sea buckthorn flies were first identified in the Netherlands (Hering, 1958) and were known in a few European countries, but they did not cause significant harm. However, Rhagoletis batava caused harm to the sea buckthorn cultivation in western Siberia and the Altai region (Kolomiec, 1970; Shamanskaya, 2006). Since 2001, it has rapidly spread in Russia and areas of Europe and the damage they have done have being observed. Soon in 2014, it began to cause severe damages to crops in several countries such as Belarus, Latvia, Lithuania, Germany and Poland. In 2015, Rhagoletis batava were recorded in the sea buckthorn fields in Estonia and Finland, and in the same year, a monitoring study in Hungary found adult flies. This became the basis for confirming that Rhagoletis batava had spread from Siberia to Europe, which posed a number of question before researchers, as to why the Siberian population is more destructive than the European population?

In 1970, Kolomyetz considered the Siberian Sea Buckthorn flies as a new subspecies, in other words, he identified it as RHAGOLETHIS BATAVA OBSCURIOSA (KOLOMIEC, 1970). Kolomyetz identified the Siberian Sea buckthorn fly as a subspecies because he believed that it was symptomatically different from the European species. Russian researchers and sea buckthorn growers have widely used the name of this species. However, since it has not been proven to be a subspecies spread in Siberia, it is considered to be a species that spread from Siberia to Europe. Thus, in Europe, the native species of sea buckthorn flies occur in both alien species from Siberia.

The Siberian species is more adaptable and more aggressive, and several factors influenced it to spread to Europe. These include, climate change, or the humid and warm climate has provided a positive effect on its reproduction. It is also related to the increase in fodder reservoir or sea buckthorn cultivation. The study of the flight dynamics of sea 
buckthorn flies is relatively well studied. According to a study in Lithuania, the flight of flies lasted from last ten days of June to August, with a peak of activity in the first ten days of mid-July. According to a study in 2016, flies were recorded in traps between June 30 and August 8, and the number of flies caught in traps between July 14 and 18 was high, but flies were trapped between July 21 and August 22 . The peak of the flight was not clearly visible at this time, and statistical estimates suggest that it took place between July 28 and August 18. In 2018, flies were trapped between June 26 and July 9, and the peak of the flight took place between July 20 and 24.

During the years of observations, the dynamics of fly populations fluctuated greatly, which was directly related to the climatic conditions of those years. This study was similar to the observations in Germany, but according to Shamanskaya (2014) and Zhao (2017) (Dominykas Aleknavicius. 2019) it began 2-3 weeks before the flight of flies in Siberia and the Asian part of Mongolia and Russia. In conclusion, the flight of flies in Europe lasts for 6 weeks, starting in late June and ending in August, culminating in ten days

\section{CONCLUSIONS}

- We marked the spread of Sea buckthorn fly (Rhagoletis batava) at 223 points in 22 soums of 6 provinces of Mongolia and described it on the distribution map.

- Due to the fact that the spread of Sea buckthorn fly covers an area with a unique and comprehensive system of mountains and gobi deserts, the amount of precipitation is uneven or not similar, and

\section{REFERENCES}

1. Azzaya D and Dulamsuren J "Meteorological monitoring instructions, Agricultural meteorology” Ulaanbaatar, 2003.

2. Arturs Stalazs, Maksims Balalikins 2017. Country Checklist of Rhagoletis Loew (Diptera: Tephritidae) for Europe, with Focus on R. Batava and Its Recent Range Expansion. in mid-July to ten days in mid-August. Also, the start time of the flight and the start of the flight lasts about 20 days each year.

Sea buckthorn flies are species which are well adapted to warm environments. According to a research by M. A. Prokofieva, the sum of the useful temperatures for the development of the worms is $312^{\circ} \mathrm{C}$ and the fluctuations are plus \pm 67.5 degrees. The flight time of an adult insect is associated with thermal fluctuations. If the spring is warm, the weather is hot or sunny in the first ten days of June, and the sum of useful heat is $336-380^{\circ} \mathrm{C}$, or the spread of flies begins on June 9-22, early release of flies starts and in the case of medium-term spreads, the spread of flies continues in the middle of June, when the sum of useful heat is 271-278 degrees Celsius, or in the cool days, the beginning of the evening spread is considered to be the end of June and the beginning of July. During the cold spring period of the year, the dispersion of flies lasts for 6 weeks for three periods with a total useful heat of $250^{\circ} \mathrm{C}$ and the mass dispersions last one week, and the mass dispersions begin in the first ten days of July (Shamanskaya L.D 2014).

most of the territories are included in dry and cooler regions but some of them are included in wet and cold regions.

- The lifetime of Sea buckthorn flies depends on climate change and it is expected to emerge earlier and disappear late in the future, as a result, its lifetime will be increased.

Proceedings of the Latvian Academy of Sciences. Section B . Vol.71. № 3 (708):103-110

3. Burcu ÖZBEK ÇATAL, Asime Filiz ÇALIŞKAN KEÇE2, Mehmet Rıfat ULUSOY 2019. Determination of the Species of Tephritidae family (Diptera) on Cherry Orchards in Adana Province and Surroundings in Turkey. KSÜ 
Tarım ve Doğa Derg 22(3): 492-497, 2019

4. Chuluunjav $\mathrm{Ch}$ and Ganchimeg G. 2014. The study of Sea buckthorn fly in Mongolia. Journal of Agricultural Sciences. The proceedings of the Scientific Conference on the 6th anniversary of the Mongolian National Association of fruit and berry. Special serial: 25-30.

5. Druzhelyubova T.S, Makarova L.M 1972. "Weather and forecast of reproduction of pest insects" Hydrometeo-Izdat-Leningrad.

6. Dominykas Aleknavicius, Vincas Buda 2019. Trapping peculiarities, flight and mating dynamics of sea buckthorn fruit fly (Rhagoletis barava) in Lithuania. Zemdirbyste Agriculture, Vol 106. 1: 81-86.

7. Gomboluudev P 2018. "Mongolian third national communication" Ulaanbaatar. p123

8. Ichinkhorloo $\mathrm{D}$, Otgonbileg $\mathrm{Kh}$ and Oyungerel D. 2016. Spread and resource of the natural sea buckthorn of Mongolia.

9. Ian M. White and Marlene M. ElsonHarris 1994. Fruit flies of economic significance: Their identification and bionomics.

10. Kandybina M.N. 1972. The Study of Fruit Flies (Diptera, Tephritidae) of the People's Republic of Mongolia. Entomological Review, LI, 4: 909-918.

11. Keys to insects of the Far East of Russia. Volume VI. Part 3. Edited by P.A. Lehr. 2004. Compiled. Korneev V.A, Ovchinnikov O.G. Sem. Tephritidae - Piedflies: 456, 479, 482

12. Korneyev V.A, Mishustin R.I, Korneyev S.V 2017. The Carpomyni Fruit flies (Diptera:Tephritidae) of Europe, Caucasus and Midle East: new records of pests, with improved keys. Vestnik zoologii, 51(6):453-470. Mongolian Academy of Sciences. National Atlas of Mongolia. Ulaanbaatar. 2009.

13. Laagan B, Avdai Ch and Tsendeekhuu Ts. 1976. The sea buckthorn.
14. Munkhtsetseg B, Jagdag D, Uranchimeg A and Ganbat D. 2019. The effect of pest insects and diseases to natural sea buckthorn shrinkage in Zavkhan River basin, Mongolia. Journal of Agricultural Sciences. Special number. Pages 60-68.

15. Natsagdorj L. 2009. Climate change Ulaanbaatar. p29.

16. Natsagdorj L and Dagvadorj D. 2010. Adaptation to Climate Change, Ulaanbaatar. p.73

17. Oyun-Erdene A, Ulziituya A 2014. Journal of Agricultural Sciences. Special serial of the Scientific Conference on the 60th anniversary of the Mongolian National Association of fruit and berry.

18. Sainzaya Ts and Undarmaa D 2014. The results of the study of the most harmful Sea buckthorn flies in the western region. Journal of Agricultural Sciences №12 (01): 34-138

19. Shcherbakov M.V 2016. Tephritid flies of the southeast of western Siberia: Preliminary results and research prospects. $\mathrm{X}$ All-Russian Dipterological Symposium. Krasnodar: 342-347.

20. Shamanskaya L,SD. 2014. Seabukthorn fly. Bio-ecology and control.

21. Tendeekhuu Ts. 2012. The sea buckthorn and the natural protection. The presentation.

22. The Carpomyni Fruit flies (Diptera:Tephritidae) of Europe, Caucasus and middle east: new records of pests, with improved keys. Vestnik zoologii.51(6):453-470.

23. Xing-Jian Wang 1996. The fruit flies (Diptera: Tephritidae) of the East Asian region. Acta zootaxonomica Sinica:188,189.

24. Zeynalov A.S 2018. Features of Bioecology of Sea buckthorn flies Rhagoletis batava Hering in the Central Non-Chernozem Region of Russia. Russian Agricultural Sciences. Vol 44, №4:335-339. 